\title{
Membangun Model Perbankan Syariah yang Transparan, Akuntanbel, Responsibility, Independensi dan Fairness Perspektif Pengetahuan (Survey pada Perbankan Syariah di Propinsi Jambi)
}

\author{
Mukhzarudfa \\ Universitas Jambi
}

\begin{abstract}
Jambi Province is one of the provinces with the largest Muslim population in Indonesia, with such a large population, Jambi Province should have been a pioneer and direction for the development of Islamic banking and finance in Indonesia. Nevertheless, the contribution of sharia business is still very low compared to conventional business, in 2016 the sharia banking market share is still less than 5\%. For the development of sharia banking in the future, the specificity of the application of sharia principles in totality, demanding products and contracts of Islamic banking must have a link with real sector activities. This is where an understanding of governance and a professional business model and the aspects of muamalat fiqh are needed. Islamic banking as a modern banking needs to be managed with the principles of modern governance, which are in accordance with sharia principles, for this reason, this study tries to uncover and analyze how the model of sharia corporate governance implementation in sharia financial institutions. This study aims to explore the model of disclosure mechanism of sharia banking corporate governance in Jambi Province. The sample banks in the study consisted of 7 Islamic banks in Jambi Province. Research is done by using Qualitative Methods. Data analysis is done using the content analysis method. The results of the study show that for 2016, the sharia banking model that is transparent, accountable, responsive, independent and fairness analyzed can be grouped into four aspects, namely the regulatory aspects, organizational structure, process aspects and functions. From the aspects analyzed, it can be concluded that the Islamic commercial banks in implementing their governance show that bank management has implemented the principles of governance fairly well, in accordance with the provisions of the applicable legislation. And there are still significant weaknesses in the application of its sharia governance structure model. The sharia governance model that is built is to produce a sharia banking model that is transparent, accountable, responsible, independent and fairness that is applied in Jambi Province at the same time as the provisions that apply to sharia banking internationally.
\end{abstract}

Keywords: Corporate Governance, Shariah Banking, Shariah Governance

\section{PENDAHULUAN}

Propinsi Jambi adalah salah satu Propinsi dengan jumlah penduduk muslim terbesar di Indonesia, dengan jumlah penduduk yang besar tersebut, seharusnya Propinsi Jambi sudah menjadi pelopor dan kiblat pengembangan perbankan syariah di Indonesia, untuk tahun 2016 Pertumbuhan perbankan syariah di Jambi tergolong relatif kecil, yakni enam 6 persen. Kondisi ini tak sebanding dengan jumlah penduduk muslim di Propinsi Jambi. Presentasenya sekitar 90 persen dari jumlah penduduk Jambi. Kepala Perwakilan Bank Indonesia Provinsi Jambi, Vielloeshant Carlusa, mengakui hal itu, saat membuka Jambi Syariah Expo (JSE) 2017, Menurut Carlusa, idealnya pertumbuhan perbankan syariah di Propinsi Jambi berkisar 20 - 25 persen. Alasannya, jumlah penduduk muslim sangat besar jumlahnya. Salah satu faktor lambatnya perkembangan perbankan syariah di Jambi, adalah pola pikir masyarakat. Masih banyak orang beranggapan bank syariah hanya "milik" umat muslim. Padahal, bank syariah melayani kebutuhan masyarakat terhadap jasa dan produk perbankan yang tidak diakomodir di bank umum. (Info Jambi, com, 2017). Industri keuangan berbasis syariah di Propinsi Jambi terus berkembang dan mengambil bagian dalam perputaran ekonomi, namun belum signifikan. Bank Indonesia Provinsi Jambi mencatat, aset perbankan syariah di Jambi hingga Juli 2017 sebesar Rp 2,55 triliun atau tumbuh 6,23 persen. Meskipun relatif kecil, aset perbankan di Provinsi Jambi naik 15 persen dibanding posisi yang sama tahun 2016. Penghimpunan dana pihak ketiga (DPK) naik 7,39 persen dengan total DPK Rp 1,13 triliun. Pembiayaan perbankan syariah di Provinsi Jambi Juli 2017 naik 9,42 persen. Total pembiayaannya Rp 2,35 triliun. Dari sisi jumlah aset, jangkauan fisik dan produk keuangan yang ditawarkan juga berkembang dan beragam. (Statistik Perbankan Syariah 2017). 
Pertumbuhan perbankan syariah sangat dipengaruhi oleh kebutuhan masyarakat sebagai pengguna bank syariah. Kebutuhan masyarakat akan terus meningkat seiring dengan tingkat pemahaman masyarakat terhadap keberadaan dan manfaat bank syariah (Investor, 2012). Perbankan syariah sebagai sebuah perbankan yang moderen perlu dikelola dengan prinsip-prinsip tata kelola yang moderen, untuk itu maka pengelolaan perbankan syariah harus didasarkan pada sebuah mekanisme tata kelola korporasi syariah yang moderen. Kerangka tata kelola perusahaan merupakan fondasi untuk implementasi efektif dari tata kelola yang baik. World Bank mendefinisikan makna tata kelola perusahaan sebagai berikut: ...suatu perpaduan antara hukum, peraturan perundang-undangan dan praktik yang dilakukan oleh sektor privat atas dasar sukarela yang memungkinkan perusahaan untuk menarik modal keuangan dan tenaga kerja, berkinerja secara efisien, dan dengan semua itu dapat secara berkesinambungan menghasilkan nilai-nilai ekonomi jangka panjang bagi para pemegang sahamnya, dan pada saat yang bersamaan memperhatikan kepentingan para pemangku kepentingan dan masyarakat secara keseluruhan (Maassen, 2000).

Prinsip-prinsip tata kelola perusahaan yang diterbitkan oleh OECD (Prinsip CG OECD) dinyatakan bahwa kerangka kerja tata kelola perusahaan harus mendorong transparansi dan pasar yang efisien, sejalan dengan peraturan hukum, dan membagi dengan jelas kewajiban dan tanggung jawab di antara otoritas yang menjalankan fungsi pengawasan, pengaturan dan penegakan hukum (OECD, 2004). Untuk mencapai keberhasilan dalam jangka panjang, pelaksanaan tata kelola perusahaan perlu dilandasi oleh integritas yang tinggi; oleh karena itu, etika bisnis merupakan bagian integral dari tata kelola perusahaan (KNKG, 2011). Prinsip CG OECD tentang tata kelola menyebutkan bahwa kerangka tata kelola perusahaan harus melindungi hak-hak pemegang saham dan memfasilitasi pelaksanaan hak-hak pemegang saham. Hak-hak dasar pemegang saham termasuk hak untuk: 1) mendapatkan metode pendaftaran kepemilikan; 2) mengalihkan atau memindahkan saham; 3) mendapatkan informasi yang relevan dan material tentang korporasi secara tepat waktu dan teratur; 4) berpartisipasi dan memberikan suara dalam RUPS; 5) mengangkat dan memberhentikan Direksi dan Dewan Komisaris; dan 6) mendapatkan bagian dalam keuntungan perusahaan (OECD, 2004).

Propinsi Jambi, hingga tahun 2016 ini memiliki 7 perbankan syariah serta perusahaan terbuka yang dikontrol oleh satu keluarga atau grup atau pemerintah, Dalam hal ini, yang menjadi persoalan adalah kecenderungan pemegang saham pengendali untuk mengambil keputusan yang menguntungkan kepentingan mereka, tetapi dapat merugikan kepentingan pemegang saham non pengendali. Fenomena ini menyebabkan perlindungan terhadap investor kecil masih lemah, sehingga bank syariah kurang menarik perhatian berbagai pihak. Untuk pengembangan keuangan syariah ke depan, khususnya produk dan akad keuangan syariah, kekhusunan prinsip syariah menuntut produk dan akad keuangan syariah yang harus memiliki linked dengan aktivitas sektor riil. Disinilah dibutuhkan pemahaman tata kelola dan model bisnis yang profesional serta aspek fiqih muamalatnya. Berdasarkan latar belakang tersebut di atas, penelitian ini mencoba membangun model tata kelolas syariah pada perbankan syariah dan selanjutnya dapat membangun model perbankan syariah yang transparan, akuntanbel, responsibility, independensi dan fairness yang didasarkan pada tatakelola korporasi syariah yang moderen. (Adisetiawan, 2011)

\section{Landasan Teori.}

Kaen (2003), menyatakan bahwa mekanisme tata kelola (corporate governance) pada dasarnya menyangkut masalah siapa yang seharusnya mengendalikan jalannya kegiatan korporasi dan mengapa harus dilakukan pengendalian terhadap jalannya kegiatan korporasi. Secara legal, yang dimaksud dengan dengan siapa adalah para pemegang saham perusahaan korporasi. Sedangkan yang dimaksud dengan mengapa adalah karena adanya hubungan antara pemegang saham dengan berbagai pihak lainnya yang berkepentingan terhadap korporasi tersebut. Secara umum mendefinisikan mekanisme tata kelola (Corporate Governance) sebagai suatu sarana, mekanise, dan struktur yang berperan sebagai pengecekan atas self serving behavior manajer. Secara teoritis, manajer menerima kewenangan dari pemilik perusahaan untuk mengelola kegiatan perusahaan seharihari seharusnya memiliki komitmen, loayalitas, dan motivasi yang semata-mata ditunjukan untuk kepentingan 
perusahaan yang dikelolanya. Namun, dalam kenyataan sering terjadi keputusan yang diambil manajemen tidak ditujukan untuk kepentingan perusahaan, tetapi justru untuk kepentingan para eksekutif dan sebagai akibatnya merugikan kepentingan para eksekutif dan sebagai akibatnya merugikan kepentingan perusahaan dan pemilik perusahaan. Untuk mencegah kemungkinan terjadinya self serving behavior oleh manajer, pengelolaan perusahaan seharusnya dapat dilakukan secara terbuka, sehingga memberikan peluang bagi pemilik dan berbagai pihak yang berkepentingan lainnya untuk melakukan monitoring terhadap prilaku manajer di dalam mengelola perusahaan. (Adisetiawan dan Yunan, 2016(

Konsep tata kelola syariah secara historis, memiliki kisamaan dengan konsep hisbah dalam sejarah masyarakat Islam klasik, yaitu sebagai lembaga khusus yang mengawasi berjalannya pasar sesuai dengan prinsip-prinsip syariah. Kedua sistem ini memiliki banyak kesamaan khususnya pada fungsi kelembagannya, yaitu untuk menengakkan prinsip dan aturan syariah dalam organisasi perusahan atau pasar (Rama, 2015). Prinsip-prinsip mengenai tata kelola perusahaan secara Islami (Syariah) dan sesuai dengan praktek-praktek terbaik yang berlaku di perbankan nasional maupun internasional serta nilai-nilai yang ada di Bank Syariah, merupakan dasar bagi Perseroan untuk terus berupaya menjadi Bank terbaik dalam penerapan corporate governance selama ini. Adapun nilai-nilai dimaksud tercermin dari aspek-aspek sebagai berikut: 1) Keterbukaan; 2) Akuntabilitas; 3) Tanggung Jawab; 4) Profesional; 5) Kewajaran; dan 6) Sikap Kepedulian. Perbankan syariah perlu memberikan perhatian yang lebih besar terhadap Mekanisme tata kelola, setidaknya ada beberapa alasan mengapa hal ini diperlukan. (1) Dalam peraturan perbankan disebutkan bahwa perbankan syariah harus mematuhi hukum syariah, (Archer et al, 1998). Sebagian besar deposan dan investor perbankan syariah mempunyai keyakinan yang tinggi bahwa dana mereka dikelola sesuai dengan aturan syariah (Chapra and Ahmed, 2002). Selanajutnya Chapra dan Ahmed juga menyebutkan bahwa sebagian besar deposan perbankan syariah siap untuk menarik dana mereka jika perbankan gagal beroperasi sesuai dengan aturan syariah; (2) Chapra and Ahmed, (2002) menyatakan ..... "Islamic banks have unrerstricted investment account holder. These account holders appear to be part of the agency conflicts since they participate in the profit and loss like shareholders"...; (3) Claessens, (2006), menyatakan bahwa sebagian besar Perbankan Islam beroperasi di pasar negara berkembang, dimana institusi kelembagaan yang cendrung lemah. Tingginya konsentrasi kepemilikan dan kontrol keluarga, lemahnya transparansi dan praktik pengungkapan. Keberadaan meknisme tata kelola diharapkan dapat mengendalikan prilaku pengelola agar dapat mengelola kegiatan korporasi secara terbuka, sehingga pemilik mempunyai kesempatan untuk mengkaji berbagai keputusan dan pengambilan keputusan pengelola, serta menilai keefektifan keputusan pengelola.

Penelitian Hasan (2011), mengenai praktik tata kelola syariah di Malaysia, Sejumlah negara di Timur Tengah dan Inggris menyimpulkan bahwa model syariah yang diadopsi oleh berbagai negara bervariasi. Perbedaan tersebut dikarenakan adanya perbedaan peraturan yang mengatur tentang sistem tata kelola syariah di Negara tersebut. Mekanisme tata kelola perbankan Islam didasarkan pada penelitian yang dilakukan oleh Chapra dan Ahmed ( 2002), Haniffa dan Hudaib (2007) dan Safieddine (2009) mekanisme tata kelola yang perlu diungkapkan oleh pernbakan Islam di Indonesia didasarkan pada Undang-undang No. 21 Tahun 2008. Peraturan Bank Indonesia No.11/33/PBI/2009 tanggal 7 Desember 2009 tentang Pelaksanaan GCG Bagi BUS dan UUS.

Adapun Mekanisme tata kelola tersebut meliputi:

A. Dewan Komisaris

Dewan Komisaris sebagai organ perseroan bertindak atas nama pemegang saham, bertugas melakukan pemantauan dan pengawasan serta memberikan nasihat kepada Direksi atas pengelolaan perseroan. Adapun tugas dan tanggung jawab Dewan Komisaris sesuai dengan Undang-undang No.21 Tahun 2008 tentang Perbankan Syariah dan ketentuan dalam PBI mengenai $G C G$ yang berlaku, serta Anggaran Dasar Perseroan antara lain adalah :

a. Dewan Komisaris wajib melaksanaan tugas dan tanggung jawab sesuai dengan prinsip-prinsip $G C G$; 
b. Dewan Komisaris wajib melakukan pengawasan atas terselenggaranya pelaksanaan $G C G$ dalam setiap kegiatan usaha BUS pada seluruh tingkatan dan jenjang organisasi;

c. Dewan Komisaris wajib melaksanakan pengawasan terhadap pelaksanaan tugas dan tanggung jawab Direksi, serta memberikan nasihat kepada Direksi;

d. Dalam melakukan pengawasan, Dewan Komisaris wajib memantau dan mengevaluasi pelaksanaan kebijakan strategis perseroan;

e. Dewan Komisaris wajib memastikan bahwa Direksi telah menindaklanjuti temuan audit dan/atau rekomendasi serta komitmen dari hasil pengawasan Bank Indonesia, auditor internal, Dewan Pengawas Syariah dan/atau auditor eksternal;

f. Memberi nasihat atas pengarahan strategis perseroan;

g. Memastikan bahwa sistem dan kebijakan pengaturan internal dan manajemen risiko berjalan;

h. Mengembangkan praktek $G C G$ agar diterapkan oleh perseroan;

i. Mengawasi efektifitas praktek penerapan $G C G$ dan apabila diperlukan mengubah atau menyesuaikan agar memperbaiki penerapan $G C G$;

j. Memastikan bahwa semua temuan audit intern dan ekstern telah ditindaklanjuti sesuai dengan komitmen yang telah diberikan oleh Direksi.

B. Dewan Pengawas Syariah

Dewan Pengawas Syariah (DPS) merupakan badan independen yang bertugas melakukan pengarahan (directing), pemberian konsultasi (consulting)/nasihat dan atau saran, melakukan evaluasi (evaluating) dan pengawasan (supervising) kegiatan bank syariah dalam rangka memastikan bahwa kegiatan usaha bank syariah mematuhi (compliance) prinsip-prinsip syariah sebagaimana telah ditentukan oleh fatwa dan syariah Islam. Berdasarkan ketentuan yang tercantum dalam Peraturan Bank Indonesia No.11/33/PBI/2009 tanggal 7 Desember 2009 tentang Pelaksanaan GCG Bagi BUS dan UUS, disebutkan antara lain : 1) DPS wajib melaksanakan tugas dan tanggung jawab sesuai dengen prinsip-prinsip $G C G$; 2) Memberikan nasihat dan saran kepada Direksi serta mengawasi kegiatan Bank agar sesuai dengan Prinsip Syariah; 3) Menilai dan memastikan pemenuhan Prinsip Syariah atas pedoman operasional dan produk yang dikeluarkan Bank; 4) Mengawasi proses pengembangan produk baru Bank agar sesuai dengan fatwa yang Dewan Syariah Nasional (DSN) - Majelis Ulama Indonesia (MUI); 5) Meminta fatwa kepada DSN - MUI untuk produk baru Bank yang belum ada fatwanya; 6) Melakukan review secara berkala atas pemenuhan Prinsip Syariah terhadap mekanisme penghimpunan dana dan penyaluran dana serta pelayanan jasa Bank; 7) Meminta data dan informasi terkait aspek syariah dari satuan kerja Bank dalam rangka pelaksanaan tugasnya.

C. Direksi

Direksi mempunyai tugas dan tanggung jawab sebagaimana tercantum dalam Undang-undang No.21 Tahun 2008 tentang Perbankan Syariah, PBI tentang GCG yang berlaku serta Anggaran Dasar Perbankan Syariah. Direksi Bank wajib selalu berpedoman kepada peraturan perundang-undangan yang berlaku termasuk memenuhi prinsip kehati-hatian dan prinsip syariah serta memenuhi ketentuan tentang pelaksanaan $G C G$, antara lain sebagai berikut :

1. Direksi merupakan organ Perseroan yang bertanggung jawab penuh atas pelaksanaan pengelolaan untuk kepentingan Perbankan Syariah sesuai dengan maksud dan tujuan serta mewakili Perseroan baik didalam maupun diluar pengadilan sesuai ketentuan Anggaran Dasar Perbankan Syariah;

2. Direksi wajib melaksanakan $G C G$ dalam setiap kegiatan usaha Bank pada seluruh tingkatan atau jenjang organisasi;

3. Direksi wajib menindaklanjuti temuan audit dan/atau rekomendasi dari hasil pengawasan Bank Indonesia, auditor intern, Dewan Pengawas Syariah dan/atau auditor ekstern.

D. Komite Audit

Komite Audit mendorong terciptanya praktik yang sehat dalam pelaporan keuangan, manajemen risiko, pengendalian internal dan etika bisnis yang baik. Dalam pelaksanaannya, Direksi bertanggung jawab 
sepenuhnya atas penyajian laporan keuangan yang sesuai dengan standar dan ketentuan yang berlaku, kecukupan pengelolaan risiko dan sistem pengendalian internal serta kepatuhan terhadap peraturan yang berlaku. Tugas Komite Audit adalah membantu Dewan Komisaris dalam hal : 1) Menindaklanjuti hasil temuan Internal Audit Division (IAD) sesuai dengan kebijakan atau pengarahan yang diberikan oleh Dewan Komisaris; 2) Ketua Komite Audit, bersama Direktur Utama menandatangani laporan hasil audit kepada Bank Indonesia atas setiap temuan audit yang diperkirakan dapat mengganggu kelangsungan usaha Perbankan Syariah; 3) Mengevaluasi hasil temuan pemeriksaan oleh IAD; 4) Meminta Direksi untuk menindaklanjuti hasil temuan pemeriksaan IAD; 5) Memberikan persetujuan tentang pengangkatan dan pemberhentian Kepala IAD oleh Direksi dan dilaporkan kepada Bank Indonesia.

E. Komite Pemantau Resiko

Komite Pemantau Risiko telah menjalankan tugas dan tanggung jawab secara profesional dan independen tanpa campur tangan dari pihak manapun yang tidak sesuai dengan peraturan dan ketentuan yang berlaku. Adapun tugas KPR sesuai dengan ketentuan yang berlaku, antara lain : 1) Melakukan evaluasi atas kebijakan dan strategi manajemen risiko yang disusun Manajemen secara tahunan; 2) Melakukan evaluasi terhadap laporan pertanggungjawaban Direksi atas pelaksanaan kebijakan manajemen risiko; 3) Mengevaluasi langkah-langkah yang diambil oleh Direksi dalam rangka memenuhi peraturan Bank Indonesia dan peraturan perundang-undangan lain yang berlaku dalam rangka pelaksanaan prinsip kehatihatian, khususnya yang berkaitan dengan manajemen risiko; 4) Melakukan evaluasi terhadap permohonan atas usulan Direksi yang berkaitan dengan transaksi atau kegiatan usaha yang melampaui kewenangan Direksi untuk dapat digunakan oleh Dewan Komisaris sebagai dasar pengambilan keputusan.

F. Komite Remunerasi dan Nominasi (KRN)

Komite Remunerasi dan Nominasi (KRN) Bank Muamalat telah menjalankan tugas dan tanggungjawabnya secara profesional dan independen, tanpa campur tangan dari pihak manapun sesuai dengan peraturan dan ketentuan yang berlaku. Tugas dari Komite Remunerasi dan Nominasi antara lain : 1. Menentukan kriteria seleksi dan prosedur nominasi bagi Anggota Dewan Komisaris, Direksi dan Karyawan Senior; 2. Mengajukan nominasi Anggota Dewan Komisaris dan Direktur melalui Direksi untuk diajukan kepada Bank Indonesia (untuk dilakukan penilaian kemampuan dan kepatutan) dan Pemegang Saham sebelum pelaksanaan RUPS dengan mempertimbangkan secara seksama usulan-usulan dari Pemegang Saham; 3. Mengevaluasi jumlah Anggota dan komposisi Dewan Komisaris dan Direksi; 4. Mempersiapkan proposal penunjukkan atau penunjukan ulang Anggota Dewan Komisaris dan Direktur kepada Pemegang Saham.

G. Komite-Komite Eksekutif Direksi

Untuk membantu Direksi dalam menjalankan tugasnya selain Kepala Divisi maka sesuai struktur organisasi dan berdasarkan Surat Keputusan Direksi telah dibentuk 6 (enam) Komite Eksekutif, yang dipimpin langsung oleh Direktur Utama (Dirut) dan/atau Direktur terkait, yaitu sebagai berikut : a. Assets \& Liabilities Committee (ALCO); b. Komite Pengarah Teknologi Informasi/Information Technology Steering Committee (ITSC); c. Komite Manajemen Risiko/Risk Management Committee (RMC); d. Komite Pembiayaan/Financing Committee; e. Komite Layanan/Service Committee (SC),f. Komite Limit Kewenangan Investasi/Investment Limit Committee

H. Fungsi Audit Interen

Perbankan Syariah memiliki Sistem Pengendalian Intern (SPI) dalam menjalankan mekanisme pengawasan yang dilakukan oleh berbagai lini perusahaan. Dalam SPI telah terkandung sistem dan prosedur yang jelas serta telah ditetapkan oleh Direksi dan Dewan Komisaris. Sedangkan pengawasan dan evaluasi terhadap pelaksanaan SPI ini dilakukan oleh Divisi Audit Intern, Divisi Kepatuhan, Divisi Manajemen Risiko, dan Manajemen Bank.

I. Fungsi Audit Eksteren

Berdasarkan ketentuan dalam PBI No. 3/22/PBI/2001 tanggal 13 Desember 2001 tentang Transparansi Kondisi Keuangan Bank sebagaimana diubah dengan PBI No.7/50/PBI/2005 tanggal 29 November 2005 
dan Surat Edaran Bank Indonesia No.7/57/DPbS tanggal 22 Desember 2005 tentang Hubungan Antara Bank yang Melaksanakan Kegiatan Usaha Berdasarkan Prinsip Syariah, Kantor Akuntan Publik, Akuntan Publik, Dewan Pengawas Syariah dan Bank Indonesia antara lain telah mensyaratkan beberapa hal dalam pemilihan/penunjukan AP/KAP ini, disamping adanya persyaratan intern dari Perbankan Syariah antara lain persyaratan bahwa dalam melakukan seleksi harus disesuaikan dengan persyaratan dan/atau ketentuan/charter yang berlaku.

Penelitian mengenai membangun model perbankan syariah yang transparan, akuntabel, responsibility, independensi dan fairness perspektif pengetahuan masih jarang dilakkan di Indonesia. Membangun tata kelola syariah (syariah governance) pada perbankan Islam khususnya di Indonesia, belum banyak dilakukan. Bankbank Islam, merupakan lembanga keuangan dengan indentitas berbasis agama, mereka diharapkan dapat mematuhi nilai-nilai etika yang Islami dalam kegiatan operasi yang dilakukan. Selain ketentuan yang berlaku, Islam mendorong dijalankannya praktik tata kelola yang baik. Dalam Islam, Tata Kelola bertujuan untuk melindungi kepentingan semua stakeholders dengan patuh terhadap prinsip syariah (Hasan, 2009). Oleh karena itu pengkajian tentang bagaimana membangun syariah governance pada perbankan syariah harus terus dilakukan, agar Bank-bank Islam tersebut dapat tumbuh dan berkembang serta memberikan kontribusi yang lebih besar dalam perekonomian nasional dan kehidupan secara keseluruhan.

\section{METODE PENELITIAN}

Obyek penelitian adalah apa yang menjadi titik perhatian dari suatu penelitian. Penelitian ini dilakukan untuk memperoleh bukti empiris mengenai model atau mekanisme tata kelola (corporate governance) pada perbankan syariah di Propinsi Jambi, oleh karena itu yang menjadi obyek dalam penelitian ini adalah aspek syariah mekanisme tata kelola syariah, yang meliputi aspek regulasi, struktur organisasi dan fungsi syariah governance. Metode penelitian yang digunakan adalah dengan menggunakan pendekatan Metode penelitian kualitatif yaitu penelitian dilakukan dengan mengeksplor dan memferifikasi berbagai dokumen-dokumen untuk mendapatkan gambaran model mekanisme tata kelola (corporate governance) syariah pada perbankan syariah di Propinsi Jambi.

Populasi sasaran dalam penelitian ini adalah semua bank umum syariah yang terdapat di Propinsi Jambi. Ada 7 bank umum syariah pada akhir tahun 2016. Adapun yang menjadi sampel dari penelitian ini adalah delapan bank yang laporan tahunannya tersedia di web perusahaan, yaitu: (1) Bank Muamalat, (2) Bank Syariah Mandiri, (3) Bank BNI Syariah, (4) Bank BRI Syariah, (5) Bank Syariah, (6) Bank. Data yang dikumpulkan adalah data primer dalam bentuk kualitatif, yang diperoleh secara mendalam melalui berbagai bentuk dokumen seperti peraturan-peraturan hukum, surat edaran dan lain sebagainya yang terkait dengan perbankan syariah di Indonesia dan Propinsi Jambi. Data tersebut peneliti dapatkan melalui anual report tahun 2016, serta peneliti melakukan penelusuran di website resmi lembaga perbankan terkait. Untuk data sekunder lainnya yang dapat menunjang hasil penelitian didapatakan dari berbagai sumber; seperti hasil penelitian, jurnal yang terkait dengan obyek penelitian yang sedang dilakukan, serta buku-buku teks terkait. Analisis data dilakukan dengan menggunakan analisis konten terhadap dokumen-dokmen hukum untuk mendapatkan gambaran tentang model tata kelola syariah di perbankan syariah di Propinsi Jambi. Analisis konten atau analisis isi ini dilakukan dan dibahas secara mendalam terhadap isi dari sautu teks, suatu teks atau dokumen dapat diteliti dengan didasarkan pada katagori atau ketentuan yang dikembangkan.

\section{HASIL DAN PEMBAHASAN}

Diskripsi perkembangan perbankan syariah di Propinsi Jambi sampai dengan bulan Juli tahun 2017 adalah sebagai berikut. Kepala Perwakilan Bank Indonesia Provinsi Jambi V. Carlusa menyatakan bahwa total aset perbankan syariah pada bulan Juli tahun 2017 tercatat sebesar Rp 2,55 triliun atau sebesar 6,23persen dari total aset perbankan di Propinsi Jambi. Aset perbankan syariah pada posisi Juli 2017 telah mengalami kenaikan sebesar 15\% jika dibandingkan dengan posisi yang sama tahun lalu. Jumlah aset, jangkauan fisik dan produk 
keuangan yang ditawarkan telah berkembang dan semakin beragam. Produk keuangan Islam saat ini telah digunakan dalam produk retail komersial, perusahaan dan pemerintahan, termasuk didalamnya pertanian, manufaktur, keuangan, dagang, transportasi, dan pembangunan infrastruktur. (Tribun Jambi, 2017). Berikut peneliti akan melakukan diskripsi analisis terhadap model syariah governance bagi lembaga perbankan syariah di Propinsi Jambi. Analisis akan dilakukan dengan berdasarkan pada aspek regulasi, struktur organisasi proses, dan fungsi dari syariah governance. (Rama, 2015) Analisis berdasarkan pada ketentuan yang berlaku di Indonesia dan secara internasional.

\section{Analisis Aspek Regulasi}

Aspek regulasi analisisnya difokuskan dengan melihat apakah sistem syariah governance telah diatur dalam bentuk undang-undang tersendiri, yaitu terpisah dari undang-undang perbankan konvensional yang sudah ada. Selain itu, juga melihat apakah diatur dalam bentuk undang-undang saja atau diikuti dengan peraturan lembaga otoritas terkait seperti bank central, Otoritas Jasa Keuangan dan guidelines tentang kerangka penerapan shariah governance lembaga keuangan syariah di masing-masing yurisdiksi. Keberadaan perbankan syariah di Indonesia, diatur melalui undang-undang tersendiri dengan nama UU No. 21 Tahun 2008 tentang Perbankan Syariah. Sebelum lahirnya UU Perbankan Syariah, industri perbankan syariah Masih diatur secara bersama melalui UU perbankan konvensional, yaitu UU No. 10 Tahun 1998, hasil amandemen UU No. 7 Tahun 1992 tentang Perbankan. UU tentang Perbankan Syariah Selanjutnya dijelaskan lebih detail dan operasional Melalui Peraturan Bank Indonesia (PBI) dan Surat Edaran Bank Indonesia (SEBI).

UU No. 21 Tahun 2008 tentang Perbankan Syariah, menyatakan bahwa pihak yang bertugas untuk melakukan pengawasan kepatuhan bank syariah terhadap pelaksanaa prinsip-prinsip syariah disebut sebagai Dewan Pengawas Syariah (DPS). Setiap bank syariah atau bank konvensional yang membuka Unit Usaha Syariah (UUS) wajib membentuk DPS yang bertugas memberikan nasehat dan saran kepada direksi serta mengawasi kegiatan bank agar sesuai dengan prinsip syariah. UU Perbankan Syariah tidak memberikan penjelasan yang rinci tentang DPS, tetapi Bank Indonesia melalui PBI dan SEBI yang dikeluarkan, memberikan perincian dan guidelines terkait dengan dewan pengawas syariah beserta pelaksanaan GCG pada bank syariah. Setidaknya terdapat tiga PBI dan dua SEBI yang menguraikan tentang sistem tata kelola syariah Atau shariah governance pada bank syariah.

Pelaksanaan GCG pada bank syariah dijelaskan melalui PBI No. 11/33/PBI/2009. PBI ini secara umum menjelaskan tentang konsep GCG bagi bank syariah dan UUS serta bagaimana peran masing-masing dari Dewan Komisaris, Direksi, Komite-Komite, dan Dewan Pengawas Syariah. Dalam PBI ini juga dijelaskan tentang format self assessment pelaksanaan GCG pada bank syariah. Pada bagian pengawasan syariah dijelaskan tentang mekanisme pengangkatan anggota DPS, masa jabatan, tugas dan tanggung jawab, mekanisme pelaporan hasil pengawasan DPS dan sanksi bagi DPS yang tidak melaksanakan kewajibannya. Kalau kita coba analisis lebih lanjut bagaimana pelaksanaan GCG pada bank syariah sebagaimana dijelaskan melalui PBI No. 11/33/PBI/2009. Terlihat bahwa peraturan tersebut belumlah mengambarkan bagaimana seharusnya pelaksaaan GCG secara menyeluruh yang sifatnya syariah. Peraturan tersebut hanya meruapakan penyesuaian dari peraturan bank Indonesia yang sebelumnya telah diperuntukan bagi bank konvensional. Untuk itu diperlukan alternatif model GCG yang benar-benar secara totalitas berbasis syariah, sehingga pada akhirnya dari aspek regulasi ini Jambi atau Indonesia diharapkan dapat memiliki UU model kerangka GCG syariah yang komprehensif.

\section{Analisis Aspek Organisasi}

Analisis aspek struktur organisasim shariah governance di Indonesia harus didasarkan pada ketentuan perundangan dan peraturan yang berlaku. Dari analisis aspek organisasi yang ada dapat dilihat dan diakui bahwa adanya dua level pengawasan syariah. Level pengawasan pertama adalah: dewan syariah pada level nasional yang biasa disebut sebagai Dewan Syariah Nasional (DSN), dan Kedua adalah dewan syariah pada 
level perusahaan yang disebut Dewan Pengawas Syariah (DPS). Kedua lembaga pengawasan secara jelas disebutkan dalam UU No. 21 Tahun 2008 dan PBI No.6/24/PBI/2004. DSN adalah lembaga yang dibentuk oleh Majelis Ulama Indonesia (MUI) yang mempunyai fungsi melaksanakan tugas-tugas MUI dalam mengatasi masalah-masalah yang berhubungan dengan aktivitas keuangan syariah. MUI Adalah organisasi perkumpulan ulama yang berasal dari berbagai organisasi Islam di Indonesia yang berstatus sebagai organisasi nonpemerintahan. Salah satu tugas pokok DSN adalah mengkaji, menggali serta merumuskan nilai dan prinsipprinsip hukum Islam (syariat) dalam bentuk fatwa untuk dijadikan pedoman dalam kegiatan transaksi di lembaga keuangan syariah. Fatwa yang dikeluarkan oleh DSN menjadi pedoman bagi Lembaga keuangan yang menawarkan Layanan keuangan syariah. Keorganisasian DSN statusnya adalah merupakan organisasi nonpemerintah tetapi fatwa yang dikeluarkan khususnya terkait dengan transaksi keuangan bersifat megikat bagi pelaku industri keuangan syariah sebagaimana termaktub dalam Pasal 26 UU No. 21/2008 tentang Perbankan Syariah.

\section{Analisis Aspek Proses.}

Analisis aspek proses dalam praktik syariah governance meliputi:

a) Pengangkatan dan pemberhentian,

Pengangkatan dan pemberhentian DPS pada bank syariah persyaratannya diatur melalui PBI No.11/3/PBI/2009 dan SEBI No. 12/13/DPbS/2010 . Langkah pertama adalah bank syariah wajib mengajukan proposal pengajuan calon anggota DPS yang disertai dengan dokumen pendukung kepada Bank Indonesia setelah mendapatkan rekomendasi Majelis Ulama Indonesia. Bank Indonesia kemudia melakukan persetujuan atau penolakan atas permohonan yang diterima berdasarkan pada pemeriksaan Kelengkapan dokumen dan wawancara Yang dilakukan. Dengan demikian, Bank Indonesia dan DSN bertanggungjawab dalam memastikan calon anggota DSN yang ditunjuk sudah memenuhi persyaratan peraturan yang ada. Hal yang menarik dari ketentuan prosedur ini adalah bahwa DPS tidak ditunjuk semata oleh masing-masing bank tetapi berdasarkan pada hasil fit and proper tes yang dilakukan oleh BI dan DSN. Pemberhentian anggota DPS bisa dilakukan jika yang bersangkutan tidak melaksanakan tugasnya dengan baik seperti tidak melakukan penasehatan, penilaian, pengawsan dan review terhadap pelaksanaan prinsipprinsip syariah pada bank.

b) Komposisi, dan rangkap jabatan

Jumlah anggota DPS berdasarkan peraturan PBI tidak kurang dua orang atau paling banyak $50 \%$ dari jumlah anggota direksi. Satu dari anggota DPS bertindak sebagai ketua.Anggota DPS tidak boleh merangkap jabatan melebihi empat lembaga keuangan syariah. DPS juga tidak boleh merangkap sebagai konsultan di bank umum syariah (BUS) dan atau unit usaha syariah UUS).

c) Persyaratan,

Adapun persyaratan keanggotaan DPS adalah harus memiliki (i) integritas berupa akhlak yang baik, komitmen terhadap perundang-undangan dan pengembangan bank syariah; (ii) kompotensi berupa pengetahuan dan pengalaman dibidang muamalah dan pengetahuan di bidang perbankan dan keuangan secara umum; dan (iii) reputasi kuangan yang baik. Namun demikian, PBI tersebut tidak mensyaratkan perlunya keanggota DPS berasal dari latar belakang yang berbeda terutama dari segi kualifikasi, pengalaman dan pengetahuan.

\section{Analisis Aspek Tugas dan Fungsi}

Analisis ini didasarkan pada ketentuan Undang-Undang Perbankan Syariah Nomor 21 Tahun 2008. Adapun yang menjadi tugas dan fungsi Dewan Pengawas Syariah (DPS) adalah memberikan saran dan nasehat kepada direksi serta melakukan pengawasan terhadap kegiatan perbankan agar berjalan sesuai dengan prinsipprinsip syariah. Keputusan yang telah dikeluarkan oleh DPS yang berkaitan dengan kegiatan usaha perbankan syariah adalah bersifat mengikat dan memiliki kekuatan hukum. Ketentuan mengenai aspek tugas dan fungsi 
didasarkan pada Peraturan Bank Indonesia (PBI) No. 6/24/PBI/2004. Serta surat Edaran Bank Indonesia (SEBI) No. 12/13/DPbS/2010.

\section{SIMPULAN}

Masih ditemukan praktik tata kelola yang dilakukan yang belum sesuai dengan prinsip syariah, beragam praktik tata kelola syariah dan lebih lanjut diakui hal itu adalah karena kekurangan dan kelemahan dalam kerangka tata kelola saat ini. Berdasarkan keseluruhan temuan survei, kerangka kerja tata kelola syariah yang ada perlu lebih jauh ditingkatkan. Untuk mengadopsi praktik governance syariah khususnya standar tata kelola AAOIFI dan pedoman IFSB. Untuk implementasi yang lebih baik, diperlukan membentuk komite tata kelola di tingkat Dewan Direksi dan mengeluarkan laporan tata kelola Syariah tahunan. Standar tata kelola syariah sangat disarankan untuk dibuat hukum wajib, leh pihak yang berwenang akan mengeluarkan standar untuk kepatuhan dengan semua hukum dan peraturan dan tanggung jawab yang berkaitan dengan tata kelola Syariah. Dewan Syariah yang tepat dan koordinasi serta terintegrasi dengan kerangka kerja tata kelola syariah akan dapat menyelesaikan masalah kewenangan Dewan Syariah. Kerangka kerja koordinasi Dewan Syariah harus dilakukan untuk dapat memfasilitasi komunikasi dan interaksi yang efektif di antara Dewan Syariah. Bank syariah harus memiliki kebijakan tertulis mengenai penyebaran informasi juga meningkatkan tingkat pengungkapan terutama dalam keuangan dan non keuangan mereka aspek-aspek seperti remunerasi dewan Syariah dan masalah-masalah material yang terkait para karyawan. Disarankan untuk mengungkapkan rincian informasi Dewan Syariah, pengumuman syariah, laporan syariah dan bagan organisasi melalui situs web mereka. Model syariah governance yang dibangun untuk menghasilkan Model Perbankan syariah yang Transparan, Akuntanbel, Responsibility, independen dan fairness yang diterapkan di Propinsi Jambi pada prinsinya belum memenuhi prinsip syariah yang berlaku untuk perbankan syariah secara totalitas secara Internasional.

\section{DAFTAR PUSTAKA}

Adisetiawan, R., and Yunan Surono, 2016, Earning Management and Accounting Information Value: Impact and Relevance, Business, Management and Economics Research, 2(10), 170-179

Adisetiawan, R., 2011, Relevansi Nilai Informasi Akuntansi pada Indeks LQ45, Jurnal Akuntabilitas, 1(1), 119126

Bank Indonesia, 2009. Peraturan Bank Indonesia (PBI) No. 11/33/PBI/2009 Tanggal 7 Desember 2009. Tentang Pelaksanaan Good Corporate Governance Bagi Bank Umum Syariah (BUS) dan Unit Usaha Syariah (UUS)

Bank Indonesia, 2010.Surat Edaran (SE) BI No.12/13/DPbS tanggal 30April 2010.Tentang Pelaksanaan Good Corporate Governance Bagi Bank Umum Syariah (BUS) dan Unit Usaha Syariah (UUS).

Chapra, M.U. and Ahmed, H. (2002), Corporate Governance in Islamic Financial Institutions,Islamic Research and Training Institute, Islamic Development Bank, Jeddah.

Claessens, S. 2006. Corporate governance of Islamic banks.available at: www.ifc.org/ifcext/corporategovernance.nsf/content/islamic_fin_institution_governance (accessed 1 August 2011).

Haniffa, R. and Hudaib, M. 2007. Exploring the ethical identity of Islamic banks via communication in annual reports. Journal of Business Ethics, Vol. 76, pp. 97-116

Hasan, Z. 2009. Corporate governance: Western and Islamic perspectives, International Review of Business Research Papers, Vol. 5 No. 1, pp. 277-93.

Hasan, Z. 2011. A survey on Shari'ah governance practices in Malaysia, GCC countries and the UK: Critical appraisal, International Journal of Islamic and Middle Eastern Finance and Management, Vol. 4

Info Jambi Com, 2017. Masih Kecil, Perbankan Syariah Terus Tumbuh. 19 Sept 2017

Kaen, Fred R. 2003. A Blueprint for Corporate Governance, Amacom, American Management Associaion. 
Kementerian Hukum dan Hak Asasi Manusia, 2008.Undang-Undang Nomor 21 Tahun 2008 Tentang Perbankan Syariah.

KNKG, 2011. Buku Pedoman Umum Good Governance Bisnis Syariah (GGBS). KNGK dan LPPI, Jakarta, 2011.

Majalah Investor, 2012. 20 Top Syariah. Agustus 2012. Edisi XIV/230

Maassen, P. A. M. 2000. The Changing Roles of Stakeholders in Dutch University Governance. European journal of education,

OECD, 2004.OECD Principles of Corporate Governance.Head of Publications Service,OECD Publications Service,2, rue André-Pascal,75775 Paris Cedex 16, France.

Otoritas Jasa Keuangan (OJK). 2017. Statistik Perbankan Syariah 2017.

Rama, A. 2015. Analisis Kerangka Regulasi Model Syariah Governance Lembaga Keuangan Di Indonesia. Journal of Islami Economica Lariba, Volume 1, Issue 1.

Safieddine, A. (2009), Islamic financial institutions and corporate governance: new insights foragency theory”, Corporate Governance: An International Review, Vol. 17 No. 2, pp. 142-58.

Salinan Surat Edaran Otoritas Jasa Keuangan Nomor 10/SEOJK.03/2014 tentang Penilaian tingkat kesehatan bank umum syariah dan unit usaha syariah

Tribun Jambi, 2017. Aset Perbankan Syariah Capai Rp 2,55 T 